\title{
Perlindungan Hukum Terhadap Wisatawan Asing dalam Konteks Kesetaraan Rasial di Indonesia
}

\author{
Putu Baruna Giri Waisnawa ${ }^{1}$ \\ 1Program Studi Magister (S2) Ilmu Hukum' Fakultas Hukum Universitas Udayana, \\ E-mail: baruna.waisnawa@gmail.com
}

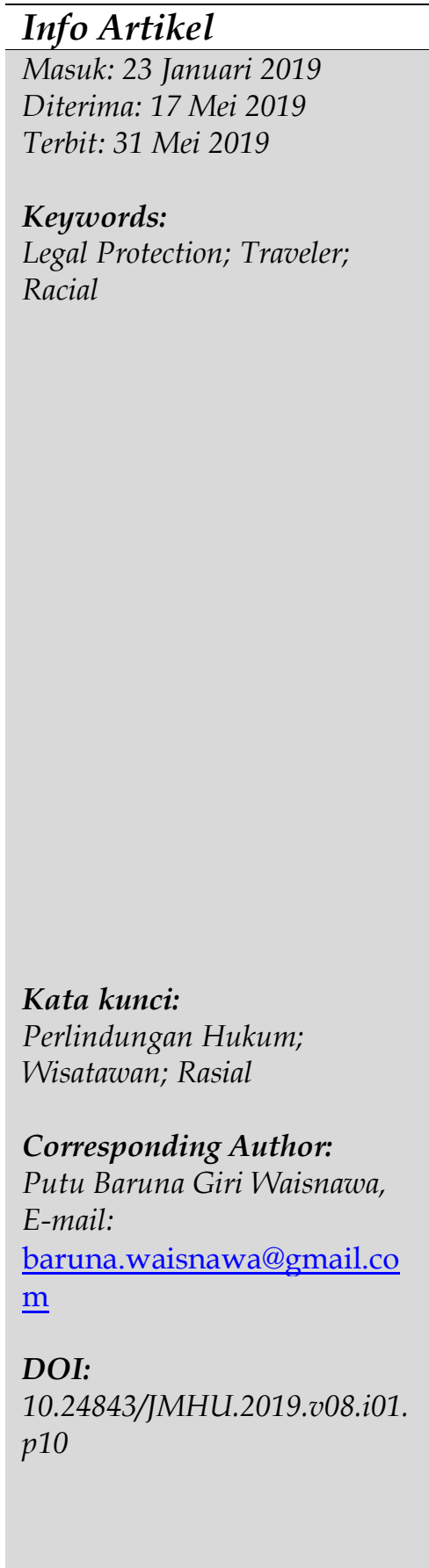

\begin{abstract}
Tourism is the third largest contributor to foreign exchange, Indonesia with its diversity and beauty of the island and cultural diversity make Indonesia one of the world's tourism destinations where 2018 numbers of tourists visiting Indonesia reached $11,929,542$. Tourists are present are dominated by tourists from China, they come to Indonesia using tour packages from travel which of course with a limited budget, of course, the treatment of tourists come with tour packages with limited budgets will be different, it is very important to provide protection law in the context of racial equality which would certainly provide a balance and justice for foreign tourists, considering tourism is one of the contributors to foreign exchange, this study aims to collaborate legal protection for foreign tourists in the context of human rights, especially in racial equality. This study uses normative research methods with a legislative approach and methods and norms that serve as the basis for acting for citizens and society on what they deem appropriate. The results study show that foreign tourists who travel to Indonesia are protected as stipulated in the provisions of Article 28C of the 1945 Constitution of the Republic of Indonesia, as well as Article 13 and Article 27 of Law Number 39 of 1999 concerning Human Rights and Article 19 of Law Number 10 of 2009 concerning Tourism; The right to travel is a right that is owned by everyone. The state has an obligation to respect and protect and fulfill the right to travel.
\end{abstract}

\begin{tabular}{l} 
Abstrak \\
\hline Pariwisata merupakan penyumbang terbesar devisa negara \\
ketiga selain komoditi minyak dan gas, Indonesia dengan \\
keanekaragamannya dan dengan keindahan pulau dan ragam \\
budayanya menjadikan Indonesia sebagai salah satu destinasi \\
pariwisata dunia dimana pada tahun 2018 angka wisatawan \\
yang datang berkunjung ke Indonesia mencapai 11.929 .542 juta \\
jiwa. Wisatawan yang hadir didominasi oleh wisatawan asal \\
cina, dimana mereka pada umumnya datang ke Indonesia \\
menggunakan paket tur dari travel agen yang tentunya dengan \\
anggaran biaya yang terbatas, perbedaan perlakuan terhadap \\
wisatawan yang datang dengan paket tur yang anggarannya \\
terbatas akan berbeda, sangatlah penting untuk memberikan \\
suatu perlindungan hukum dalam konteks kesetaraan ras yang \\
tentunya akan memberikan suatu keseimbangan dan keadilan \\
bagi wisatawan asing, mengingat pariwisata merupakan salah \\
satu penyumbang devisa negara, studi ini bertujuan untuk
\end{tabular}


mengolaborasi perlindungan hukum bagi wisatawan asing dalam konteks hak asasi manusia khususnya dalam kesetaraan rasial. Studi ini menggunakan metode penelitian normatif dengan pendekatan perundang undangan dan kaedah maupun normanorma yang menjadi dasar bertindak bagi warga maupun masyarakat terhadap apa yang mereka anggap pantas. Hasil studi menunjukkan bahwa wisatawan asing yang berwisata ke Indonesia mendapat perlindungan sebagaimana yang telah diatur dalam ketentuan Pasal 28C UUD RI Tahun 1945, serta Pasal 13 dan Pasal 27 UU Nomor 39 Tahun 1999 Tentang Hak Asasi Manusia dan Pasal 19 UU Nomor 10 Tahun 2009 Tentang Kepariwisataan; Hak berwisata merupakan hak yang dimiliki oleh setiap orang. Negara memiliki suatu kewajiban untuk menghormati serta melindungi dan memenuhi hak berwisata, yang tentunya di dalam kegiatan pariwisata tersebut baik wisatawan dan pengusaha pariwisata memiliki hak dan kewajiban.

\section{Pendahuluan}

Indonesia merupakan Negara dengan kawasan kepulauan tropis yang memiliki daya tarik tersendiri di mata pelancong dunia, atau bisa dikatakan para wisatawan asing. Indonesia sendiri merupakan negara dengan jumlah kepulauan terbanyak yakni sekitar 17.5041. Sektor pariwisata merupakan sektor yang amat sangat diperhitungkan mengenai penerimaan devisa yakni salah satu dari tiga pendapatan devisa negara, selain komoditi minyak mentah dan gas alam (bumi) serta minyak dari perkebunan kelapa sawit, maka dari itu sektor pariwisata merupakan sektor yang dapat dikatakan sangat penting, karena sedikit tidaknya akan membantu pemerintah mendapatkan tambahan devisa.

Menurut Pasal 1 ayat (1) UU No. 10 Tahun 2009 Tentang Kepariwisataan, poin dari wisata itu sendiri merupakan suatu aktivitas perjalanan baik sendiri maupun beramairamai mendatangi suatu tempat tertentu yang bertujuan untuk menikmati alam objek wisata tersebut seperti rekreasi, mempelajari keunikan maupun kearifan lokal tempat tersebut dalam jangka waktu tertentu. ${ }^{2}$

Sedangkan, Pengertian Pariwisata sendiri menurut WTO adalah "The activities of persons traveling to and staying in places outside their usual environment for not more than one consecutive year for leisure, business and other purposes". "Pariwisata merupakan aktivitas seseorang yang melakukan perjalanan dan tinggal di daerah tujuan di luar lingkungan kesehariannya untuk waktu tertentu untuk tujuan liburan, bisnis, dan

${ }^{1}$ Badan Pusat Statistik. (2017). Luas Daerah dan Jumlah Pulau Menurut Provinsi, 2002-2016. Retrieved from https://www.bps.go.id/statictable/2014/09/05/1366/luas-daerah-danjumlah-pulau-menurut-provinsi-2002-2016.html.

2 Ethika, T. D. (2016). Pengembangan Pariwisata Berbasis Budaya Berdasarkan Ketentuan Undang-Undang Nomor 10 Tahun 2009 Di Kabupaten Sleman. Kajian Hukum, 1(2), 133-158.

${ }^{3}$ Richardson, J. I., \& Fluker, M. (2004). Understanding and managing tourism. NSW Australia: Pearson Education Australia, h. 6. 
lainnya". Orang yang sedangkan melakukan wisata dapat disebut dengan wisatawan. ${ }^{4}$

Berdasarkan data dari Kementerian Pariwisata RI Tahun 2018 jumlah wisatawan yang berkunjung ke Indonesia periode Januari-Desember mengalami kenaikan di bandingkan Tahun lalu sebesar 11.929 .542 juta jiwa atau tumbuh sebesar 11,81\% di bandingkan bulan yang sama pada periode Tahun lalu ${ }^{5}$. Jumlah tersebut bukanlah angka yang sedikit karena, mengingat daya Tarik dari daerah pariwisata Indonesia itu sendiri yang terkenal dengan kearifan lokal serta keramahtamahan penduduk asli Indonesia yang terkenal dengan senyum ramahnya dan keindahan pantai, laut dan pegunungan yang menghiasi sepanjang wilayah Indonesia, tak hayal membuat para wisatawan asing datang dan mengunjungi setiap daerah yang ada di Indonesia, wisatawan asal Cina saat ini mendominasi kunjungan wisata ke Indonesia di susul dengan jumlah 224 ribu wisatawan atau sekitar 14,61\% yang disusul selanjutnya oleh wisatawan asal Malaysia 13,07\%, Timor leste 10,63\%, Australia 8,36\%.6

Jika dilihat dari jumlahnya, maka dapat dikatakan untuk saat ini wisatawan asal Cina masih memimpin dalam jumlah angka kedatangan di Indonesia, meskipun jumlah wisatawan asing asal Cina cukup tinggi, tetapi mayoritas kedatangan mereka untuk berwisata di Indonesia berupa paket tur dengan jumlah rombongan yang bervariatif, yang bisa dikatakan untuk anggarannya sangat terbatas bahkan cenderung cukup, yang biasanya hanya berwisata di Indonesia 5-6 hari, dimana paket tour mereka sudah termasuk biaya menginap, makan serta transportasi pada saat berwisata atau bahkan terkadang sudah termasuk tiket pulang-pergi. Hal tersebut berbanding terbalik jika di bandingkan wisatawan asing lain dari beberapa negara yang berasal dari Eropa atau bahkan dari Jepang, Korea, Amerika dan Australia yang biasanya lebih memilih private tour atau tour pribadi yang jumlah rombongannya lebih sedikit sehingga dari skala kualitas mereka lebih baik, namun kalah dengan jumlah kuantitas dari wisatawan asal Cina yang datang untuk berwisata ke Indonesia dengan Jumlah rombongan tertentu.

Maka dari itu, karena dianggap menggunakan paket tour yang relatif murah, dan dengan anggaran terbatas para wisatawan asing asal Cina terkadang mendapatkan perlakuan yang kurang baik, seperti kasus yang baru-baru ini terjadi tentang adanya praktik curang mengenai pemaksaan wisatawan asing untuk berbelanja dan nantinya wajib masuk ke toko-toko itu. Dapat dikatakan bahwa toko tersebut sudah menjalin kerja sama dengan pihak travel agen dimana para wisatawan digiring dan dipaksa untuk membeli barang-barang yang belum tentu mereka inginkan yang berbahan lateks seperti bantal, sofa, kasur dan lainnya yang tentunya perlakuan tersebut bisa dikatakan tidak adil bagi wisatawan asing dengan ras tertentu, yang dapat dikatakan menggunakan jasa paket tour dengan jumlah peserta tour yang banyak yang

\footnotetext{
${ }^{4}$ Sarsiti, S., \& Taufiq, M. (2012). Penerapan Perlindungan Hukum terhadap Wisatawan yang Mengalami Kerugian di Obyek Wisata (Studi di Kabupaten Purbalingga). Jurnal Dinamika Hukum, 12(1), h. 29.

5 Kementerian Pariwisata. Data Kunjungan Wisatawan Mancanegara. Retrieved from http://www.kemenpar.go.id/post/data-kunjungan-wisatawan-mancanegara-bulanantahun-2018-januari-desember-tahun-2018

6 Kementerian Pariwisata. Statistik Wisatawan Mancanegara. Retrieved from http:/ / www.kemenpar.go.id/asp/detil.asp?c=110\&id=4007
} 
cenderung lebih murah ${ }^{7}$, perlakuan tersebut dirasa tidak adil dan sudah termasuk kategori diskrimanasi, adapun diskriminasi merupakan adanya perbedaan tindakan yang terjadi akibat argumen tertentu dimana cakupan diskriminasi cukup meluas, yakni warna kulit, ras, jenis kelamin, agama, nasional dan lain sebagainya. ${ }^{8}$

Adapun hal tersebut membuat wisatawan asing dari ras tertentu mengalami perlakuan yang tidak baik, sehingga memerlukan suatu perlindungan hukum, agar kedepannya mereka selaku wisatawan asing dapat menikmati indahnya kawasan Indonesia, serta agar terciptanya suatu keadilan yang dapat diperoleh wisatawan asing yang datang berwisata ke indonesia dengan tidak membeda-bedakan ras. Disamping itu selaku tuan rumah pun, juga mendapatkan efek positifnya dari kedatangan wisatawan asing yang berkunjung ke Indonesia.

\section{Metode Penelitian}

Adapun jenis penelitian yang diterapkan dalam penulisan jurnal ini merupakan metode kepustakaan yaitu dengan mengumpulkan bahan hukum melalui membaca dan mencatat literature atau bahan hukum yang dapat di konsepsikan sebagai suatu kaedah maupun norma yang menjadi dasar bertindak bagi warga maupun masyarakat terhadap apa yang mereka anggap pantas. ${ }^{9}$

\section{Hasil dan Pembahasan}

\subsection{Perlindungan hukum bagi wisatawan asing dalam peraturan perundang- undangan Indonesia}

Indonesia merupakan negara yang menjunjung tinggi hukum, ini sudah jelas tertuang dalam UUD 1945 Pasal 1 ayat (3), maka sudah dipastikan sesuatu hal yang ada di negeri ini akan diatur dengan aturan, guna kepentingan bersama, subjek hukum sebagai pemikul sesuatu hak serta suatu kewajiban, baik itu orang perorangan, badan hukum, maupun sebuah jabatan, dapat melakukan suatu tindakan hukum yang berdasarkan kemampuan maupun suatu kewenangan yang telah mereka miliki. Di dalam pergaulan masyarakat, telah banyak terjadi suatu hubungan hukum yang datang akibat adanya suatu tindakan dari subjek hukum tersebut. Tindakan hukum ini merupakan dasar lahirnya hubungan hukum, yakni sebuah interaksi antar subjek hukum yang memiliki relevansi hukum atau memiliki sebuah akibat hukum. Agar hubungan hukum antar subjek itu dapat berjalan secara harmonis, adil dan seimbang, dalam artian setiap subjek hukum memiliki apa yang seharusnya menjadi haknya dan dapat menjalankan kewajiban yang telah di bebankan. Hukum akan menjadi suatu aturan dalam mengatur maupun menjalankan hubungan hukum tersebut. ${ }^{10}$

7 Wema Satya Dinata. (2018). Cium Praktik Curang Pengusaha Pariwisata China. Tribun Pontianak.com. Retrieved from http://pontianak.tribunnews.com/2018/11/17/ciumpraktik-curang-pengusaha-pariwisata-china-gubernur-bali-tutup-paksa-16-toko?page=all

8 Asep Mulyana, (2016), HAM dan Pemerintah Daerah: Ikhtiar Membumikan HAM di Level Lokal, Jurnal HAM Komisi Nasional Hak Asasi Manusia, 13, h. 158.

9 Jonaedi Efendi, S. H. I., Johnny Ibrahim, S. H., \& SE, M. (2018). Metode Penelitian Hukum: Normatif dan Empiris. Depok: Prenada Media, h.124.

${ }^{10}$ Ridwan, (2006), Hukum Adiministrasi Negara, Raja Grafindo Persada, J Ridwan, H. R. (2006). Hukum Administrasi Negara, Jakarta: PT. Raja Grafindo Persada, h.265. 
Hukum dapat dikatakan diciptakan sebagai sebuah sarana atau instrument untuk mengatur suatu hak dan kewajiban subjek hukum agar masing-masing subjek hukum dapat menjalankan kewajibannya dengan baik dan mendapatkan haknya secara wajar. Disamping itu hukum dapat dikatakan berfungsi sebagai sebuah instrument perlindungan bagi subjek hukum. Menurut Sudikno Mertokusumo, hukum berfungsi sebagai perlindungan kepentingan manusia. Supaya kepentingan manusia dapat terlindungi, hukum merupakan suatu kewajiban untuk dilaksanakan. Pelaksanaan dan keberlangsungan hukum dapat dikatakan berlangsung secara normal, damai, tetapi tidak tertutup kemungkinan dapat terjadi juga karena pelanggaran hukum. Pelanggaran hukum dapat terjadi ketika subjek hukum tertentu tidak menjalankan kewajiban yang seharusnya mereka jalankan atau melanggar hak-hak subjek hukum lain. Subjek hukum yang dilanggar haknya tentunya harus mendapatkan perlindungan hukum. ${ }^{11}$ Di era reformasi seperti sekarang ini tuntutan untuk jaminan perlindungan dan jaminan untuk hak asasi manusia semakin genjar dilaksanakan, hal tersebut tentunya berkaitan dengan kekuasaan, kekuatan social serta struktur social yang ada. Indonesia sebagai negara yang menjunjung tinggi demokrasi yang tentunya kekuasaan tertinggi ada di tangan rakyat, keikutsertaan rakyat amat sangat penting diperlukan, rakyat sangat berperan penting dalam terwujudnya jaminan perlindungan hak asasi ini. ${ }^{12}$

Sebagaimana yang telah disepakati dalam konferensi World Tourism Organization atau disingkat WTO di Santiago, Chili tanggal 1 Oktober Tahun 1999 Tentang Kode Etik Kepariwisataan Dunia, dengan jelas menyebutkan bahwa Pemerintah wajib melindungi wisatawan dan memberikan informasi yang sejelas-jelasnya kepada wisatawan serta mencegah kemungkinan penyerangan atau penculikan, hal tersebut tertuang dengan sangat jelas di dalam Pasal 1 ayat 1 sampai dengan 4 yang telah di analisis oleh penulis sebagai berikut:

- Pasal 1 ayat 1

Dimana penting tentang mengenai pemahaman tentang suatu nilai etika yang tentunya menjadi dasar bagi kemanusiaan, dengan adanya suatu sikap saling menghormati dan toleransi keanekaragaman agama, keyakinan moral dan falsafah dan hal tersebut sebagai sebuah dasar landasan suatu konsekuensi dari kepariwisataan yang tentunya bertanggung jawab, serta setiap pemangku kepentingan di daerah pariwisata tersebut dalam melakukan pengembangan kepariwisataan serta wisatawan itu sendiri wajib menghormati keadaan social dan tradisi budaya serta kehidupan keseharian dari penduduk asli itu sendiri termasuk menghormati mereka yang dapat di golongkan sebagai kelompok yang dapat di kategorikan minoritas ;

- Pasal 1 ayat 2

Kegiatan atau aktivitas kepariwisataan wajib dilaksanakan secara harmoni dengan ciri khas suatu negara atau daerah yang menerima wisatawan itu sendiri dan wajib menghormati adat istiadat serta kehidupan sehari-hari serta tradisi masyarakat yang daerahnya dikunjungi oleh wisatawan;

- Pasal 1 ayat 3

${ }^{11}$ Mertokusumo, M. S., \& Pitlo, A. (1993). Bab-bab tentang penemuan hukum. Bandung: Citra Aditya Bakti, h.140.

12 Suparman Khan, (2001). Apresiasi Hak Asasi Manusia dalam rangka Demokratisasi di Indonesia. Jurnal Jurispruden-tia 1(11), h. 95. 
Masyarakat atau penduduk asli yang menerima wisatawan dan para mereka yang bergelut di bidang usaha pariwisata di daerah tersebut, hendaknya mereka wajib bersikap dengan ramah tamah dan saling menghormati antara pelaku usaha dan wisatawan serta memahami gaya hidup, cita rasa serta harapan wisatawan; serta pentingnya edukasi atau pendidikan serta pelatihan yang diberikan kepada para pelaku usaha yang tentunya iut berperan dalam melayani dan menyambut wisatawan;

- Pasal 1 ayat 4

Pemerintah memiliki kewajiban untuk melindungi wisatawan, pengunjung serta barang-barang milik wisatawan saat berkunjung; pemerintah hendaknya berkewajiban untuk memberikan pengawasan khusus terhadap keadaan tertentu yang dapat dikatakan rawan bagi wisatawan asing; tentunya pemerintah juga wajib memberikan kemudahan-kemudahan bagi wisatawan untuk mengetahui hal-hal yang bersifat penting seperti informasi, cara pencegahan, asuransi serta keamanan dan bantuan lain yang disesuaikan dengan kebutuhan wisatawan itu sendiri; pemerintah juga berkewajiban menjaga wisatawan dari kemungkinan penyerangan, ancaman, gangguan serta penculikan terhadap wisatawan maupun pekerja di bidang industry pariwisata, serta perusakan secara di sengaja terhadap unsur warisan budaya maupun fasilitas wisata serta unsur warisan cagar alam haruslah dikecam dan mendapatkan hukuman yang di sesuaikan dengan perundang-undangan yang berlaku di negara tersebut;

Dari isi Pasal 1 ayat 1 sampai dengan 4 dapat diambil kesimpulan bahwa masyarakat penerima wisatawan dan wisatawan sendiri harus saling menghormati satu sama lain serta harus bersikap toleransi serta mengerti kebudayaan masing-masing, wisatawan tersebut sendiri tentunya harus menghormati kehidupan sosial dan tradisi budaya keseharian dari kehidupan masyarakat yang akan dikunjungi wisatawan itu sendiri. Dari sisi masyarakat penerima wisatawan itu sendiri mereka hendaknya bersikap sopan, serta ramah dan menghormati wisatawan yang hadir menjumpai objek wisata serta memahami pola hidup mereka.

Sedangkan peranan dari Pemerintah dimana wisatawan itu berkunjung lebih menekankan kepada perlindungan yang harus diberikan kepada wisatawan itu sendiri, seperti yang di tegaskan dalam poin dari Pasal 1 ayat 1 UU Nomor 8 Tahun 1999 tentang perlindungan konsumen yaitu: segala macam tindakan maupun upaya yang menjamin adanya suatu kepastian hukum yang dapat memberikan perlindungan kepada konsumen, dimana konsumen dalam hal ini adalah wisatawan asing. ${ }^{13}$

Serta pemerintah berkewajiban pengawasan khusus terhadap keadaan tertentu bagi wisatawan asing yang berkunjung ke daerah tersebut dan pemerintah wajib memberikan perhatian mengenai akses serta kemudahan bagi wisatawan asing, hal-hal yang bersifat khusus dalam artian suatu informasi yang jelas tentang daerah yang akan dikunjungi oleh wisatawan itu guna menghindari hal-hal yang tidak dinginkan, selain memberikan perlindungan kepada wisatawan pemerintah juga wajib memberikan perlindungan terhadap lingkungan tiu sendiri, menurut UN-WTO salah satu peran pemerintah yang cukup penting adalah turut sadar dalam memfasilitasi maupun menyediakan suatu kebutuhan legislasi, control dan adanya regulasi yang dapat

${ }^{13}$ Rudyanti Dorotea Tobing, (2015), Aspek-Aspek Hukum Bisnis. Surabaya: Laksbang Justitia., h.249. 
diterapkan dalam bidang pariwisata, perlindungan suatu lingkungan serta pelestarian budaya dan tentunya warisan budaya itu sendiri. ${ }^{14}$

Sebagaimana yang telah diatur dalam ketentuan Pasal 28C UUD RI Tahun 1945, serta Pasal 13 dan Pasal 27 UU Nomor 39 Tahun 1999 Tentang Hak Asasi Manusia dan Pasal 19 UU Nomor 10 Tahun 2009 Tentang Kepariwisataan; Hak berwisata merupakan hak yang dimiliki oleh setiap orang. Negara memiliki suatu kewajiban untuk menghormati serta melindungi dan memenuhi hak berwisata. ${ }^{15}$

Menurut poin dari Pasal 1 ayat 1 UU No. 39 Tahun 1999 tentang Hak Asasi Manusia, dengan jelas menyebutkan bahwa: Hak Asasi Manusia adalah hak yang pada dasarnya melekat pada hakikatnya serta keberadaan manusia yang merupakan makhluk Tuhan Yang Maha Esa dan merupakan sebuah anugerah-Nya yang tentunya wajib di hormati, di junjung tinggi serta dilindungi oleh negara dengan adanya suatu hukum dan pemerintah serta setiap orang demi perlindungan terhadap martabat dan harkat dari manusia. ${ }^{16}$

Makna dari Hak Asasi Manusia merupakan hak yang tentunya melekat pada setip individu manusia sejak awal mereka di lahirkan atau bahkan saat di dalam kandungan yang berlaku seumur hidup da tidak dapat di ganggu gugat oleh siap pun. Sebagai warga negara yang menjunjung tinggi rasa persatuan dan kesatuan kita seharusnya sangat menjunjung tinggi suatu nilai hak asasi manusia tanpa membedakan, status, golongan, rasial, keturunan, jabatan, dan sebagainya. ${ }^{17}$

Maka dari itu setiap wisatawan asing yang datang dan berkunjung ke Indonesia, sudah dapat di pastikan di lindungi oleh aturan-aturan tersebut, serta tidak memandang golongan ras atau agama, sehingga seharusnya aturan tersebut dapat memberikan rasa aman dan nyaman dalam menikmati objek wisata yang tersebar di Indonesia tanpa adanya diskriminasi yang tentunya akan membuat wisatawan itu akan menjadi merasa tidak nyaman, yang sudah jelas akan membuat wisatawan itu merasa di diskriminasikan dengan adanya perbedaan pelayanan dan tanggapan dari pelaku usaha pariwisata setempat. Pelaku usaha pariwisata tidak boleh memilah atau membeda-bedakan wisatawan yang tidak ke daerahnya untuk berwisata, meskipun mereka datangnya menggunakan paket wisata yang cenderung dananya terbatas serta biasanya kedatangannya dengan rombongan, para pelaku usaha pariwisata tidak boleh membeda-bedakan wisatawan.

Tentunya hal tersebut juga akan berpengaruh kepada pelaku usaha pariwisata itu sendiri atau objek wisata yang dikunjungi yang tentunya akan mendapatkan respon positif dari para wisatawan mancanegara sendiri yang tentunya akan meningkatkan kunjungan wisatawan tersebut ke daerah objek wisata, yang tentunya akan meningkatkan penerimaan devisa negara.

14 Gde Pitana, (2009), Pengantar ilmu pariwisata. Yogyakarta: Andi., h.113.

${ }^{15}$ Putu Eva Laheri, (2015), Tanggung Jawab Negara Terhadap Kerugian Wisatawan Berkaitan Dengan Pelanggaran Hak Berwisata Sebagai Bagian Dari Hak Asasi Manusia. Jurnal Magister Hukum Udayana (Udayana Master Law Journal), 4(1), h. 129.

${ }^{16}$ Barzah Latupono, (2011), Perlindungan Hukum dan Hak Asasi Manusia terhadap Pekerja Kontrak (Outsourcing) di Kota Ambon. Jurnal Sasi, 17(3)., h.66.

17 Jazim Hamidi, (2016), Hukum Keimigrasian Bagi Orang Asing di Indonesia. Jakarta: Sinar Grafika, h. 52. 


\subsection{Hak dan kewajiban wisatawan dan pengusaha pariwisata agar terciptanya suatu keadilan dan keseimbangan dalam pariwisata}

Agar terciptanya suatu keadilan dan keseimbangan maka baik para pengusaha pariwisata maupun wisatawan tentunya harus memiliki hak serta kewajiban yang tentunya dilaksanakan dan dipikul masing-masing pihak seperti yang telah disampaikan oleh Notonegoro tentang konsep keadilan: keadilan ialah kemampuan yang dapat memberikan kepada diri sendiri serta orang lain apa yang seharusnya memiliki, apa yang telah menjadi haknya. Hubungan antar manusia yang terlibat di dalam penyelenggaraan keadilan terbentuk dalam opla yang disebut keadilan segitiga, yang tentunya meliputi keadilan (distributive justice), keadilan bertaat atau legal (legal justice), dan keadilan komutatif (komutative justice). ${ }^{18}$

Baik pelaku usaha maupun wisatawan memiliki hak dan kewajiban, agar sesuai dengan Asas Keadilan, dimana pengertian asas keadilan antara lain agar partisipasi seluruh rakyat bisa diwujudkan secara maksimal dan memberikan kesempatan kepada konsumen dan pelaku usaha untuk mendapatkan haknya dan melakukan kewajibannya secara adil. ${ }^{19}$ Hak dan kewajiban pelaku usaha menurut UU No. 10 Tahun 2009 tentang Kepariwisataan yang tertuang dalam Pasal 20 sampai dengan Pasal 26 antara lain:

- Pengusaha memiliki hak mendapatkan kesempatan yang sama dalam menjalankan usaha di bidang kepariwisataan.

- Membentuk serta menjadi suatu organisasi kepariwisataan.

- Mendapatkan akses fasilitas yang sama yang tentunya telah diatur dalam perundang-undangan

- Pengusaha memiliki kewajiban untuk memelihara serta menghormati adat istiadat, norma agama, kebudayaan dan nilai-nilai yang hidup dan melekat dalam masyarakat.

- Memberikan akses informasi yang benar dan tepat serta dapat di pertanggung jawabkan.

- Memberikan keramahtamahan, kenyamanan, perlindungan bagi keamanan wisatawan dan keselamatan wisatawan.

- Menyediakan asuransi bagi wisatawan pada kegiatan usaha pariwisata yang berisiko tinggi.

- Lebih mengedepankan penggunaan produk warga setempat, serta produk dalam negeri dan membuka kesempatan bekerja kepada tenaga kerja local.

- Meningkatkan kemampuan tenaga kerja melalui pendidikan serta pelatihan.

- Menjaga kelestarian lingkungan yang sehat, asri dan tentunya bersih.

- Menerapkan standar yang telah ditentukan perundang-undangan yang meliputi standar kompetensi.

- Setiap wisatawan memiliki hak untuk memperoleh informasi yang tepat tentang daya tarik obyek wisata yang dikunjunginya.

- Mendapatkan standar pelayanan kepariwisataan.

- Kepastian perlindungan hokum dan keamanan.

18 Salim HS, (2014), Penerapan Teori Hukum pada Penelitian Disertasi dan Tesis (Buku Kedua), Depok: Raja Grafindo. h.26.

${ }^{19}$ Abdul R. Saliman, (2014), Hukum Bisnis Untuk Perusahaan Teori dan Contoh Kasus, Cet. Ke7. Jakarta: Kencana, h. 191. 
- Pelayanan fasilitas kesehatan.

- Perlindungan hak pribadi dan

- Perlindungan asuransi untuk kegiatan pariwisata yang berisiko tinggi.

- Setiap wisatawan memiliki kewajiban menghormati dan menjaga norma agama, adat istiadat dan nilai-nilai yang hidup dalam masyarakat.

- Menjaga, melestarikan dan memelihara lingkungan,

- Ikut serta menjaga keamanan dan ketertiban lingkungan dan

- Turut serta mencegah segala macam perbuatan yang melanggar norma kesusilaan kegiatan yang berkaitan dengan pelanggaran hukum.

Tentunya hak kewajiban yang dipikul oleh pengusaha pariwisata dan wisatawan bertujuan baik, guna adanya keseimbangan antara pengusaha pariwisata dan wisatawan, dimana pengusaha mendapatkan haknya seperti mendapatkan kesempatan yang sama untuk berbisnis di bidang pariwisata, dan wisatawan mendapatkan haknya seperti perlindungan hukum dan keamanan serta perlindungan pribadi yang tentunya berlaku bagi seluruh wisatawan yang berkunjung ke Indonesia untuk berwisata, yang pada akhirnya meningkatkan citra di Indonesia di mata dunia, bahwa Indonesia merupakan negara yang aman dan nyaman untuk di kunjungi.

\section{Kesimpulan}

Pentingnya Perlindungan hukum terhadap wisatawan asing dalam konteks kesetaraan ras di Indonesia, karena wisatawan asing yang datang berkunjung beraneka ragam dan dari berbagai penjuru dunia, dengan kedatangan mereka yang melalui tur pribadi maupun paket tur, dimana paket tur tersebut anggarannya yang terbatas yang tidak ayal terkadang wisatawan asing tersebut mendapatkan perlakukan yang kurang layak dimana mereka dipaksa untuk berbelanja barang yang mereka tidak inginkan, maka dari itu penting untuk penegakan aturan yang berlaku untuk menekan kejadian seperti ini, dimana sesuai dengan poin dari Pasal 1 ayat 1 UU No. 39 Tahun 1999 tentang Hak Asasi Manusia, dengan jelas menyebutkan bahwa: Hak Asasi Manusia adalah hak yang pada dasarnya melekat pada hakikatnya serta keberadaan manusia yang merupakan makhluk Tuhan Yang Maha Esa dan merupakan sebuah anugerah-Nya yang tentunya wajib dihormati, dijunjung tinggi serta dilindungi oleh negara dengan adanya suatu hukum dan pemerintah serta setiap orang demi perlindungan terhadap martabat dan harkat dari manusia. Makna dari Hak Asasi Manusia merupakan hak yang tentunya melekat pada setiap individu manusia sejak awal mereka dilahirkan atau bahkan saat di dalam kandungan yang berlaku seumur hidup dan tidak dapat di ganggu gugat oleh siap pun. Sebagai warga negara yang menjunjung tinggi rasa persatuan dan kesatuan kita seharusnya sangat menjunjung tinggi suatu nilai hak asasi manusia tanpa membedakan, status, golongan, rasial. Dimana negara telah menjamin kebebasan berwisata. Sebagaimana yang telah diatur dalam ketentuan Pasal 28C UUD RI Tahun 1945, serta Pasal 13 dan Pasal 27 UU Nomor 39 Tahun 1999 Tentang Hak Asasi Manusia dan Pasal 19 UU Nomor 10 Tahun 2009 Tentang Kepariwisataan; Hak berwisata merupakan hak yang dimiliki oleh setiap orang. Negara memiliki suatu kewajiban untuk menghormati serta melindungi dan memenuhi hak berwisata Tentunya baik pengusaha pariwisata dan wisatawan memiliki hak dan kewajiban yang harus mereka jalani, gara terciptanya suatu keseimbangan dan keadilan. 


\section{Daftar Pustaka}

Buku

Hamidi, J., \& Mathaus, C. C. (2015). Hukum Keimigrasian Bagi Orang Asing di Indonesia. Jakarta: Sinar Grafika.

Jonaedi Efendi, S. H. I., Johnny Ibrahim, S. H., \& SE, M. (2018). Metode Penelitian Hukum: Normatif dan Empiris. Depok: Prenada Media.

Mertokusumo, M. S., \& Pitlo, A. (1993). Bab-bab tentang penemuan hukum. Bandung: Citra Aditya Bakti.

Pitana, I. G., \& Diarta, I. K. S. (2009). Pengantar ilmu pariwisata. Yogyakarta: Andi.

Richardson, J. I., \& Fluker, M. (2004). Understanding and managing tourism. NSW Australia: Pearson Education Australia.

Ridwan, H. R. (2006). Hukum Administrasi Negara, Jakarta: PT. Raja Grafindo Persada.

Salim H.S, (2014), Penerapan Teori Hukum pada Penelitian Disertasi dan Tesis (Buku Kedua), Depok: Raja Grafindo.

Saliman, A. R. (2014). Hukum Bisnis Untuk Perusahaan Teori dan Contoh Kasus, Cet. Ke-7. Jakarta: Kencana

Tobing, R. D. (2015). Aspek-Aspek Hukum Bisnis. Surabaya: Laksbang Justitia.

\section{Jurnal}

Ethika, T. D. (2016). Pengembangan Pariwisata Berbasis Budaya Berdasarkan Ketentuan Undang-Undang Nomor 10 Tahun 2009 Di Kabupaten Sleman. Kajian Hukum, 1(2), 133-158.

Khan, Suparman. (2001). Apresiasi Hak Asasi Manusia dalam rangka Demokratisasi di Indonesia. Jurnal Jurispruden-tia 1(11).

Laheri, P. E. (2015). Tanggung Jawab Negara Terhadap Kerugian Wisatawan Berkaitan Dengan Pelanggaran Hak Berwisata Sebagai Bagian Dari Hak Asasi Manusia. Jurnal Magister Hukum Udayana (Udayana Master Law Journal), 4(1). 126-137. https://doi.org/10.24843/JMHU.2015.v04.i01.p10

Latupono, B. (2011). Perlindungan Hukum dan Hak Asasi Manusia terhadap Pekerja Kontrak (Outsourcing) di Kota Ambon. Jurnal Sasi, 17(3). 59-69.

Mulyana, Asep. (2016), HAM dan Pemerintah Daerah: Ikhtiar Membumikan HAM di Level Lokal, Jurnal HAM Komisi Nasional Hak Asasi Manusia, 13, 1-225.

Sarsiti, S., \& Taufiq, M. (2012). Penerapan Perlindungan Hukum terhadap Wisatawan yang Mengalami Kerugian di Obyek Wisata (Studi di Kabupaten Purbalingga). Jurnal Dinamika Hukum, 27-44. http://dx.doi.org/10.20884/1.jdh.2012.12.1.198 


\section{Website}

Badan Pusat Statistik. (2017). Luas Daerah dan Jumlah Pulau Menurut Provinsi, 2002-2016. Retrieved from https://www.bps.go.id/statictable/2014/09/05/1366/luasdaerah-dan-jumlah-pulau-menurut-provinsi-2002-2016.html.

Kementerian Pariwisata. Statistik Wisatawan Mancanegara. Retrieved from http:/ / www.kemenpar.go.id/asp/detil.asp?c=110\&id=4007

Kementerian Pariwisata. Data Kunjungan Wisatawan Mancanegara. Retrieved from http://www.kemenpar.go.id/post/data-kunjungan-wisatawanmancanegara-bulanan-tahun-2018-januari-desember-tahun-2018

Wema Satya Dinata. (2018). Cium Praktik Curang Pengusaha Pariwisata China. Tribun Pontianak.com.

Retrieved from http://pontianak.tribunnews.com/2018/11/17/cium-praktik-curangpengusaha-pariwisata-china-gubernur-bali-tutup-paksa-16-toko?page=all.

\section{Intrumen Internasional}

World Tourism Organization about Global Code of Ethics for Tourism chile 1 October 1999

\section{Peraturan Perundang-Undangan}

Undang-Undang Dasar Republik Indonesia 1945

Undang-Undang Nomor 10 Tahun 2009 Tentang Kepariwisataan, Lembaran Negara Republik Indonesia Tahun 1990 Nomor 78, Tambahan Lembaran Negara Republik Indonesia Tahun 1990 Nomor 3427

Undang-Undang Nomor 8 Tahun 1999 Tentang Perlindungan Konsumen, Lembaran Negara Republik Indonesia Tahun 1999 Nomor 42, Tambahan Lembaran Negara Republik Indonesia Nomor 3821

Undang-Undang Nomor 39 Tahun 1999 Tentang Hak Asasi Manusia, Lembaran Negara Republik Indonesia Tahun 1999 Nomor 165,Tambahan Lembaran Negara Republik Indonesia Nomor 3886 